\title{
Species of the genus Xanthomonas infecting cereals and oilseeds in the Russian Federation and its diagnostics
}

\author{
Elena Kyrova ${ }^{1, *}$, Maria Egorova $^{2}$, and Alexander Ignatov ${ }^{2,3}$ \\ ${ }^{1}$ Russian Research Institute of Plant Protection, St. Petersburg, Pushkin, Podbelskogo, 3, 196608, \\ Russia \\ ${ }^{2}$ Russian University of People's Friendship, Moscow, Miklukho-Maklaya str., 6, 117198, Russia \\ ${ }^{3}$ PhytoEngineering R\&D Center, LLC, Moscow reg. Rogachevo, 141880, Russia
}

\begin{abstract}
Plant pathogenic bacteria of the genus Xanthomonas display high levels of genetic diversity and cause remarkable damage to about 400 plant species. In 2001-2008, a new group of strains of Xanthomonas arboricola has been found as pathogens on novel host plants such as wheat, rye, barley, tomato, sunflower, and brassicas in Russia. Physiological tests and multilocus sequence typing (MLST) analysis confirmed their position within the Xanthomonas arboricola species. The obtained draft genome sequence of Xanthomonas arboricola strain 3004 from barley plants, also virulent to sunflower, brassicas, and chestnut, has demonstrated an evidence for the lateral gene transfer (LGT) of the virulence genes. It can be suggested that the virE and other genes of T4SS, obtained due to LGT, may contribute to the host range extension. Thus, T4SS genes can be used as the target for group-specific PCR analysis of this emerging pathogen of cereals and oilseeds. We propose to use virB3, $\operatorname{vir} B 4$, and virB9 genes to design a detection system.
\end{abstract}

\section{Introduction}

The genus Xanthomonas is composed almost entirely of phytopathogenic species capable to infect Algae, Pteridophytes (ferns), Dicotyledonous and Monocotyledonous plants. There are many economically valuable crops (over 400 species) among the host plants [6]. Representatives of the genus are able to reduce both the quality and quantity of the crop yield. Due to the host specialization, Xanthomonas strains are a good model to investigate the mechanisms of host plant-pathogen virulence [11]. It was proved that the host specialization of the existing pathovars within Xanthomonas species occurred over the past few centuries, concomitant with the intensification of agriculture [13]. Xanthomonas causing leaf streak (CLS) or black chaff on cereals, and vascular (e.g. black rot) or leaf spot diseases on different oilseeds and greens, are the most harmful pathogens in Russia [10]. Cereals and oilseeds are among the main economically important crops.

\footnotetext{
*Corresponding author: blairkot@gmail.com
} 
Previously, we have found isolates of $X$. arboricola capable to infect cereals (fam. Poaceae), tomatoes (Solanum spp.), brassicas oilseeds (Brassica napus, B. rapa), and sunflower (Helianthus annum) in Russia [8]. The species $X$. arboricola is comprised of ten pathovars causing bacterial diseases of stone fruit and pomaceous fruit trees, walnut, hazelnut trees, poplar, banana, strawberry, and euphorbia [15]. Since new pathogens were able to extend the host range and retain the ability to infect initial host plants (e.g. walnut), they are further referred to as "atypical strains" or "atypical pathovars".

Strains of $X$. arboricola cause symptoms similar to $X$. translucens and $X$. campestris in the respective host plants and this feature significantly complicates their diagnostics. On the cereal leaves, the water-soaked stretched light green spots appear 10-20 days after inoculation, depending upon the average air temperature. Blackening of the upper part of spikelet scales and lateral stripes along the spikelet scales is observed on spikes. In sunflower, the pathogen causes leaf blight as well as leaf and stem spots. In oilseed rape, the pathogen causes wilting, V-shaped yellow or brown lesions and darkening of the veins. Later, the severely damaged leaves dry up or fall off.

$X$. arboricola is a common pathogen across the world. In Russia, 4 out of 10 pathovars were isolated: $X$. arboricola pv. pruni (bacterial spot of stone fruits and almond), $X$. arboricola pv. corylina (bacterial blight of hazelnut), X. arboricola pv. populi (bacterial canker of poplar), and $X$. arboricola pv. juglandis (bacterial walnut blight). However, their identity was not confirmed by molecular genetic approaches and genetic diversity was not investigated. The atypical strains capable to infect cereals, oilseeds, and other crops were isolated in Central Black Earth Region, Krasnodar and Stavropol Krai (region), Rostov, Saratov, Moscow Regions, Republics Adygea and North Ossetia-Alania [8,10].

Seeds are the most important source of primary inoculum for Xanthomonas pathogens, among rainwater, contaminated soil, insect pest, and equipment [17]. $X$. arboricola was the most frequently found pathogenic species on the seeds of cereals in Russia -22 seed lots of 181 tested ones were infected by this pathogen. Rice seeds had in average $7.1 \%$ of $X$. arboricola infection, wheat, barley and rye - 29.1\%. Other xanthomonads together infected $16.9 \%$ of rice seed lots and $58 \%$ seed lots for other cereals, including species that have not been reported as Poaceae pathogens: X. campestris, X. cynarae, X. hortorum, $X$. pisi, $X$. gardeneri, and $X$. vesicatoria [5].

The rapid and precise diagnostics of ethe seed infection is the main approach used to reduce crop losses caused by the bacterial pathogens. Traditional methods of detection of phytopathogenic bacteria in seeds include the plate-washing assay either on selective or semi-selective agar media, but there was no reported methods for the isolation of $X$. arboricola from cereals and oilseeds.

\section{Materials and Methods}

During the examination of the seed lot, we selected seeds with healthy appearance and those with visual symptoms of the disease: shrivelled, underdeveloped, grey, with withered yellowish exudate. Isolated bacteria were cultured on YDC medium at $27^{\circ} \mathrm{C}$ for 48 hours. Single colonies of bacteria similar to xanthomonads were sub-cultured and stored in $15 \%$ glycerol at $-70{ }^{\circ} \mathrm{C}$. Identification of the isolated strains was done by PCR with genusspecific primers and MLST as described elsewhere [7, 18]. All the xanthomonads were tested for hypersensitive reactions (HR) on leaves of tobacco, and the positive ones were selected for pathogenicity tests. The tests of pathogenicity for HR-positive strains were conducted on plants of families Poaceae, Brassicaceae, and Compositae. 


\section{Results}

\subsection{Plating assay}

We have developed the following protocol of $X$. arboricola isolation from seeds $[4,5]$ :

(1) Sterilize seeds in $0.5 \%$ sodium hypochlorite (10\% commercial bleach solution) for 2 min; (2) Wash seeds 3 times in sterile tap water; (3) Transfer seeds into PBS+Tween 20 solution ( $750 \mathrm{ml}$ of $1 \mathrm{x}$ PBS with $0.01 \%$ Tween 20 for $500 \mathrm{~g}$ of seeds); (4) Chill and incubate at $+4^{\circ} \mathrm{C}$ for 24 hours; (5) Place the seeds on the shaker for 30 minutes and $210 \mathrm{rpm}$; (6) Homogenize for 2 minutes at a rate of 8; (7) Filter the homogenate through the bacteriological filter and transferred sediment to the nutrient medium after 10-fold serial dilution. Application of succinate-quinate (SQ) selective medium (succinic acid - $10 \mathrm{~g} / \mathrm{l}$, quinic acid $-5 \mathrm{~g} / 1, \mathrm{~K}_{2} \mathrm{HPO}_{4}-1,5 \mathrm{~g} / \mathrm{l},\left(\mathrm{NH}_{4}\right)_{2} \mathrm{SO}_{4}-1 \mathrm{~g} / \mathrm{l}$, yeast extract $\left.-0,5 \mathrm{~g} / \mathrm{l}\right)$ is a conventional method for the detection of $X$. arboricola. On the SQ medium, bacterial colonies are smooth, oleiferous, sticky, and have smooth edges. Young bacterial colonies are yellow-pigmented. As they age, bacteria start to produce a melanin-like pigment. YPGA (yeast extract - 5g/l, peptone - 5g/l, glucose $-10 \mathrm{~g} / \mathrm{l}$, agar-agar $-12 \mathrm{~g} / \mathrm{l}$ ) and YDC (glucose $10 \mathrm{~g} / 1, \mathrm{CaCO}_{3}-20 \mathrm{~g} / \mathrm{l}$, yeast extract - 10g/l, agar-agar - 18g/1) media with antibiotics also are used for the bacterial colonies morphology analysis. Bacteria $X$. arboricola form bright yellow convex colonies on both YPGA and YDC agar. Morphologically typical colonies should be sub-cultured, purified, and stored. The suspected isolates must be tested for identity by PCR/IFA and for pathogenicity to the corresponding host plants.

The following scheme is used to assess pathogenicity to the host plants [5]:

(1) The plants are grown up to 3 or 5 leaves in $15-\mathrm{cm}$ pots with compost under optimal light and temperature conditions in a greenhouse; (2) Each plant is inoculated by cutting the leaf tips with scissors dampened in a bacterial suspension $(108 \mathrm{CFU} / \mathrm{ml})$, the bacterial suspension is prepared from a 2-day bacterial culture on the YDC medium at $28^{\circ} \mathrm{C}$; (3) The plants are incubated after inoculation at $24-28^{\circ} \mathrm{C}$, depending on the plant species. The disease symptoms are evaluated within the period of 21 days. The plant stems or leaves can also be pricked with a needle passed through a pure colony or sprayed with a bacterial suspension. In the latter case, the plants are incubated for 48 hours in a humid chamber after spraying [2]. The main disadvantage of such detection method is a laborious and timeconsuming process that needs high level of standardization of all operations. BIO-PCR in real time is used for an accurate and rapid detection of pathogenic bacteria.

\subsection{PCR assay}

To date, there are no recommended PCR diagnostic methods for phytopathogenic $X$. arboricola that affects cereals and oilseeds. The protocol for detection of $X$. translucens employs PCR system specific for the short DNA sequence located in 16S - 23S rRNA spacer flanking an alanine-tRNA gene. The primers amplify a 139-bp target fragment [2]. For detection of pathovars of $X$. campestris, a two-step PCR system was proposed. It includes a universal bacterial primer (reaction control) and primers specific to the $h r p F$ gene (part of the type III secretion system (T3SS)) [1]. Other T3SS genes are used as targets for the detection of $X$. arboricola pathovars. Such test system is based on the amplification of the $h r p C$ - $h r p D$ region [14]. In most of cases the detection PCR methods for Xanthomonas pathogens were developed for well-studied strains with a known range of host plants. Our previous study has shown that the PCR target based on T3SS genes was unsuitable for atypical strains of $X$. arboricola. PCR analysis with several T3SS genespecific conservative primers did not reveal any fragments of T3SS and T3SS Effector (T3E) genes in the strain 3004 as well as in other 32 strains of $X$. arboricola isolated in the 
Russian Federation. Genome analysis of representative strain 3004 confirmed the lack of T3SS genes in the atypical X. arboricola strains [9].

In 2014, Egorova with colleagues [4] proposed a seed assay for X. oryzae and some strains of $\mathrm{X}$. arboricola via BIO-PCR based on $\operatorname{gyrB}$ (DNA gyrase subunit $\beta$ ) gene sequences. However, the expected accuracy of such detection for atypical pathovars of $X$. arboricola is below $50 \%$. It is related to the genome features of new strains of $X$. arboricola. The $g y r B$ gene sequence, as well as another 5 housekeeping genes: $r p o D, d n a K$, pur $A, \operatorname{prp} C$, and $f a b B$, were close to $X$. campestris, $X$. euvesicatoria and $X$. oryzae species in the nucleotide sequence. Diversity of MLST genes was affected by the adaptation, thus, it eliminates the possibility of using MLST genes as a targets for the detection of the atypical $X$. arboricola strains [12].

\subsection{Bioinformatical analysis of $X$. arboricola genomes}

Next Generation Sequencing (NGS) technologies expanded the number of available for analysis genomes of genus Xanthomonas, and modern bioinformatics algorithms allow for more quick and easy comparative analysis. We used methods of comparative genomics, such as multiple and pair-wise alignments, to identify potential target genes for detection of atypical pathovars of $X$. arboricola. Pair-wise alignment of the genome sequences of str. 3004 , which is a type strain of the atypical strains and a type strain of the $X$. arboricola pv. juglandis (ATCC 49083=NCPPB 411) was performed using the Sequence-based comparison algorithm (RAST software). Multiple sequence alignment of the genome sequences of str. 3004 and complete and annotated genome sequencing of 13 other bacteria of the genus Xanthomonas were performed using the progressive Mauve algorithm (Mauve software). The pair-wise alignment revealed 249 unique nucleotide sequences against the reference genome. A detailed analysis of the found sequences showed that they have a high level of homology with $X$. campestris, $X$. hortorum, and $X$. gardneri species that may indicate a mosaic genome structure. This fact should be considered in the development of detection systems because the use of pseudo-unique genes can lead to false results.

During the analysis of the results of multiple genome alignment, we also noted the almost complete absence of unique sequences in the genome of $X$. arboricola str. 3004 . Unique nucleotide sequences found during the multiple sequence alignment corresponded to the phage Xantho Xp10 NC 004902 and acriflavin resistance gene. However, we noted that regions demonstrating a low level of homology to the other genus members exist in the genome of str. 3004. The functional annotation of the nucleotide sequences of the found regions revealed that they belong to the type IV secretion genes (T4SS).

T4SS genes of Xanthomonas have a limited level of homology within both the genus and the species. In addition, the T4SS genes also have the required level of conservatism. This is explained by the fact that mutations in the key genes such as virD4, virB8, virB9, $\operatorname{vir} B 10$, and $\operatorname{vir} B 11$ can completely disrupt the functions of the secretion machine [16]. We are exploring the possibility of using them for the detection of other members of the genus Xanthomonas. T4SS cluster of str. 3004 consists of $10 \operatorname{virB}(B 1-B 6, B 8-B 11)$ genes and a virD4 gene. We estimated the level of genetic variability of the proteins to assess the possibility of using the genes as targets for the detection system. During the analysis, genes with a relatively high level of variability, highly conservative genes, as well as the virB6 gene, which is a multi-copy gene, were excluded from the target genes. We have used $\operatorname{vir} B 3$, virB4, and virB9 genes to design a novel detection system for the atypical strains. Now we are testing the developed detection systems for atypical strains of $X$. arboricola in seeds and in the affected plants. 


\section{References}

1. T. Berg, L. Tesoriero, D.L. Hailstones, Plant Pathol, 54(3) (2005)

2. E. Duveiller, C. Bragard, Detection of Xanthomonas translucens in wheat seeds (Am Phytopath Society, 2017)

3. M.S. Egorova, E.S. Mazurin, V.A. Polityko, A.N. Ignatov, Zashchita i Karantin Rastenii, 41 (2014).

4. M.S. Egorova, A.N. Ignatov, E.S. Mazurin, RUDN Journal of Agronomy and Animal Industries, 15 (2014)

5. M.S. Egorova, Species diversity and methods of diagnostic of phytopathogenic bacteria of the genus Xanthomonas affecting Poaceae plants (Moscow, 2014)

6. A.C. Hayward, The host of Xanthomonas. Xanthomonas (Chapman \& Hall, London, 1993)

7. A. Ignatov, A. Sechler, E.L. Schuenzel, I. Agarkova, B. Oliver, A.K. Vidaver, N.W. Schaad, Phytopathology, 97(7) (2007)

8. A.N. Ignatov, N.V. Punina, E.V. Matveeva, E.SH. Pekhtereva, V.A. Polityko, K.P. Kornev, Zashchita i Karantin Rastenii, 4 (2010)

9. A.N. Ignatov, E.I. Kyrova, S.V. Vinogradova, A.M. Kamionskaya, N.W. Schaad, D.G. Luster, Genome Announc, 3(1) (2015)

10. A.N. Ignatov, M.S. Egorova, M.V. Khodykina, Zashchita i karantin rastenii, 5 (2015)

11. M.A. Jacques, M. Arlat, A. Boulanger, T. Boureau, S. Carrere, S. Cesbron, N.W. Chen, S. Cociancich, A. Darrasse, N. Denance, M. Fischer-Le Saux, Annu. Rev. Phytopathol., 54 (2016)

12. E.I. Kyrova, A.N. Ignatov, Genetic diversity of the population of the phytopathogenic bacterium Xanthomonas arboricola (smith) Vauterin et al. and analysis of the spectrum of affected agricultural plants (Krasnoyarsk, 2019).

13. N. Mhedbi-Hajri, A. Hajri, T. Boureau, A. Darrasse, K. Durand, C. Brin, M. FischerLe Saux, C. Manceau, S. Poussier, O. Pruvost, C. Lemaire, M. Jacques, PLoS One, 8 (2013)

14. S.Y. Park, Y.S. Lee, Y.J. Koh, J.S. Hur, J.S. Jung, Microbiology, 48 (2010).

15. G.S. Saddler, J.F. Bradbury, Xanthomonas. Bergey's Manual of Systematics of Archaea and Bacteria (Wiley, 2015)

16. D.P. Souza, G.U. Oka, C.E. Alvarez-Martinez, A.W. Bisson-Filho, G. Dunger, L. Hobeika, N.S. Cavalcante, M.C. Alegria, L.R.S. Barbosa, R.K. Salinas, C.R. Guzzo, C.S. Farah, Nat. Commun, 6 (2015)

17. R.P. Ryan, F.J. Vorhölter, N. Potnis, J.B. Jones, M.A. Van Sluys, A.J. Bogdanove, J.M. Dow, Nat. Rev. Microbiol., 9 (2011)

18. J.M.Young, D.C.Park, H.M. Shearman, E. Fargierc, Syst Appl Microbiol., 31(5) (2008) 